\title{
The Law Politics in Indonesia's Pancasila and Citizenship Education Curriculum Revitalization of 2013
}

\author{
Maryanto $^{1}$, Nor Khoiriyah ${ }^{1} \&$ Supriyono Purwo Saputro ${ }^{1}$ \\ ${ }^{1}$ Faculty of Social Science and Sport Education, Universitas PGRI Semarang, Indonesia \\ Correspondence : Maryanto, Faculty of Social Science and Sport Education, Jalan Sidodadi Timur Nomor 24 - \\ Dr. Cipto, Karangtempel, Semarang Timur, Karangtempel, Semarang Tim., Kota Semarang, Jawa Tengah 50232, \\ Indonesia. Tel: 62-24-831-6377 E-mail: maryanto_drs@yahoo.co.id
}

\author{
Received: July 12, $2017 \quad$ Accepted: July 18, $2017 \quad$ Online Published: August 25, 2017 \\ doi:10.5539/ass.v13n9p167 URL: https://doi.org/10.5539/ass.v13n9p167
}

\begin{abstract}
The curriculum is one component of education which is very important. It acts as a guide that program implementers use in real learning process. Dynamically, curriculum always change in order to lead to the improvement of the education system. On the subjects of Pancasila and Citizenship Education in schools for example, has undergone several changes in the curriculum, both in charge of its content and on its nomenclature, this change is needed in order to create a future generation that had Pancasila character embedded on their heart as stated in national education goals. However, in the process of Pancasila and Citizenship Education's curriculum change, it is undeniable that it is influenced by the current Law Politics as politics is what makes the rules. But what exactly is the influences of the law politics on Indonesia's Pancasila and Citizenship Education Curriculum Revitalization Of 2013?. The studies conducteed on how the Law politics influence the revitalization of Pancasila and Citizenship Education curriculum showed that (1) the Directions of Pancasila and Citizenship Education curriculum revitalization in Indonesia leads to; (2) The basic foundation establishment and implementation of the curriculum in 2013's Pancasila and Citizenship Education subject (3) the Products of Pancasila and Citizenship Education curriculum revitalization in Indonesia. The result that is a model of a good Pancasila and Citizenship Education curriculum revitalization should be implemented, monitoring and evaluation needs to be done to determine the level of achievement and expected results. Monitoring and evaluation results will serve as a recommendation to develop and or improve curriculum that will come.
\end{abstract}

Keywords: Indonesia, Law Politics, Curriculum, Pancasila, Citizenship Education

\section{Introduction}

The reformation era of Indonesia was marked by the fall of 2nd president of Indonesia Suharto, who caused corruption, collusion and nepotism (KKN) during his tenure raises the monetary crisis in Indonesia, prompting the Indonesian people to make changes in their life by creating a new order that can legally leads them towards improvement. Such changes are not only in economic and political fields, but also in the field of education. The role of education is vital in order to develop the nation's moral character of future generation, as stated in Article 3 of Law No. 20 of 2003 on National Education System, which mandates that national education serves to develop the ability and character development and civilization of the nation's dignity in the context of the intellectual life of the nation, is aimed at developing students' potentials in order to become a man of faith of God's Almighty, noble, healthy, knowledgeable, skilled, creative, independent, and become citizens of a democratic and accountable. Therefore, education provides the opportunity for all citizens to participate directly on developing their potential to the fullest. One appropriate means to develop the character of good citizens as mentioned above, are through the learning process of Pancasila and Pancasila and Citizenship Education.

Pancasila and Pancasila and Citizenship Education are unique subjects available only in Indonesia in which that focus more broadly in order to carry out the mandate in preparing responsible and role active citizens using The Pancasila As its fundamental Norm. Concept of Pancasila and Citizenship Education is related to democratic values to be the ideal citizen (Nur Silay, 2014: 1). This conformed to the mission of Pancasila and Citizenship Education as a subject that is focused on the formation of citizens able to carry out the rights and obligations to become Indonesian citizens which is intelligent, skilled character as mandated by Pancasila, the five fundamental norm of Indonesia and the Constitution of 1945 (Depdiknas 2006: 49). In accordance with what is stated by 
Cogan (1994: 4) that Pancasila and Citizenship Education is a subject in schools designed to prepare young citizens to potentially play as an active role in society. The same also is stated by David Kerr (2000: 2) as "citizenship or Pancasila and Citizenship Education is constructed to encompass the preparation of young people for their role and responsibilities as citizens and in particular the role of education "(through schooling, teaching and learning) in that preparatory process. this Pancasila and Citizenship Education is a definition which implies that the process of preparing the younger generation through school, teaching and learning process in order to participate actively and responsibly in a democratic country.

Various definition above implies that Pancasila and Citizenship Education is nothing but a role as one of the subjects in school that aims to develop, establish, and to prepare young people (students) who are committed and consistent in independence through the attitude of responsibility and participatory as citizen. However, to achieve the expected goals of the subjects Pancasila and Citizenship Education could not be separated from the curriculum therein. Curriculum is a set of plans and arrangements regarding the objectives, content and learning materials as well as the means used to guide the implementation of learning activities to achieve specific educational objectives (Law No. 20 of 2003 on National Education System). In relation to the curriculum of Pancasila and Citizenship Education in schools, are contained within a purpose, functions, the charge content (scope) designed to be implemented in the learning process through strategy, methods, and models appropriate as action to achieve the ultimate goal of Pancasila and Citizenship Education subject goals.

In line with the development of science and technology in society, both in the regional, national, or international, the curriculum should follow the dynamics of changes that lead to the preparation of learners in accordance to the national education goals. Likewise on Pancasila and Citizenship Education curriculum has undergone several changes in line with the changes that occur in the curriculum of national education. However, the course of Pancasila and Citizenship Education curriculum change can not be separated from the current law politics. The process of revitalization of Pancasila and Citizenship Education curriculum from regime to regime has changed both its names and payload contents. This done in an effort to achieve the aspired goal. Zembylas (2009) explains that the existing political problems will affect the pattern of curriculum development of Pancasila and Pancasila and Citizenship Education in fostering critical thinking of students in the existing political problems. Then the challenges in the curriculum development of Pancasila and Pancasila and Citizenship Education is how to develop the discourse and practice of citizenship that can foster civic awareness and active participation of learners (Ghasempoor, Ali, et al, 2012: 113)

Pancasila and Citizenship Education subjects in the curriculum in 2013 has changed its nomenclature into Pancasila and Pancasila and Citizenship Education, formerly known as the Pancasila and Citizenship Education curriculum of KTSP (2006) and Citizenship in the curriculum of KBK (2004). The return of "Pancasila" as the name of the subjects of Pancasila and Pancasila and Citizenship Education in the curriculum in 2013 was influenced by the ruling regime to actualize Pancasila in the whole life of the nation. Curriculum development direction are based on the content, pedagogical models, competency to be achieved, and the scoring system.

\section{Main Problem}

Politic is essentially a means to achieve certain goals, while the law is a tool to achieve justice. Legal politics can be interpreted as a legal policy to be applied or implemented nationally by a government of a particular country. Padmo Wahjono (1986.1991) explains that the politics of law is the basic policy of direction, form, and content through the process of formation, implementation and enforcement. In Relation to the revitalization of the curriculum, legal politics is defined as a government's policy in curriculum development towards the improvement of education set by the authorities and have the power of law as a cornerstone in the implementation of the educational process in the school to achieve the objectives of national aspired that the intellectual life of the nation. Law politics in the revitalization of the curriculum in 2013's subjects that is Pancasila and Pancasila and Citizenship Education in the form of (1) the directions of revitalization of the Pancasila and Pancasila and Citizenship Education subject is based on Pancasila as a basis of ideals and the 1945 Constitution as the source of the supreme law of the entire Indonesian legal product, (2) the legal basis underlying the implementation of the curriculum in 2013 subjects Pancasila and Pancasila and Citizenship Education, (3) the results of revitalization and implementation of the curriculum in 2013's Pancasila and Pancasila and Citizenship Education subjects must be analyzed which the author will do in this Article.

\section{Discussion}

\subsection{Direction of 2013's Pancasila and Citizenship Education Subject Curriculum Leads To}

Education is a conscious and deliberate effort to create an atmosphere of learning and a learning process for students to actively develop their potential in order to achieve the spiritual power of religion, self-control, 
personality, intelligence, character, and skills. According to Horace Man (in Michael Watz, 2011: 38) study provides an opportunity to improve the physical, mental, and spiritual generation of people. Education in the formal school environment. One of the advantages of formal education is to have a formal curriculum and writing executed in a planned, systematic, and more fundamental (Sukmadinata, N. S, 2012: 2). Curriculum as an essential condition for schooling, so the curriculum can not be separated from educational or teaching.

The curriculum has a central position in the whole education that leads to all the activities to achieve educational goals. The curriculum must be dynamic as the development time, thus the need for the process of curriculum change towards improvement. On the subjects of Pancasila and Pancasila and Citizenship Education curriculum change process is influenced by political reform in the form of national education policy as part of a national climate policy progress.

In the reform era in Indonesia has experienced three changes in the curriculum that Competency Based Curriculum (CBC) in 2004, the Education Unit Level Curriculum (SBC) in 2006, and in 2013 the curriculum in 2013 until now. Direction of development of the curriculum in 2006 to the curriculum in 2013, among others, (1) Development of Science and Technology, (2) The need for competence in the future, (3) Changes in the learning process (of the students were given a year to students to find out), (4) the scoring system (from output-based to one based on process and output), (5) The need of an additional lesson. Rationally directions of curriculum development in 2013 include (1) the internal challenges that the state of education is associated with the demands of education refers to the eight (8) National Education Standards include strander content, process standards, competency standards, standards of teachers and education personnel, standards of facilities and infrastructure, standard management, financing standards and assessment standards of education; (2) The external challenges are associated with globalization and various issues of environmental issues and the advancement of technology and information, the rise of the creative and cultural industries, and the development of education at the international level; (3) Completion of mindset; (4) Strengthened governance curriculum; and (5) Strengthening materials (Annex of Permendikbud No. 58 of 2014).

Subjects Pancasila and Pancasila and Citizenship Education in 2013 included in the curriculum of general subjects group A. Permendikbud No. 58 of 2014 on Curriculum 2013 School SMP / MTs and Permendikbud No. 59 of 2014 on Curriculum 2013 High School / Madrasah Aliyah, chapter 5, verse (2) explained that the general subjects in group A is a curricular program that aims to develop the competence of attitude, knowledge competence, and competence skills of learners as a base and strengthening capabilities in the life of society, nation and state. Charges and learning reference Pancasila and Pancasila and Citizenship Education and developed by the national government.

In accordance to this problem, Moses Chikwe (2012: 16) said that Pancasila and Citizenship Education should emphasize on the process of building national identity and patriotism of society, it is in accordance with the direction of development of Pancasila and Citizenship Education in the 2013 curriculum, namely the formation of learners into a man who has a sense of nationhood and patriotism imbued by the values of Pancasila, the Constitution of the Republic of Indonesia in 1945, the spirit of unity in diversity and the commitment of the Republic of Indonesia (NKRI). In addition to it, Pancasila and Pancasila and Citizenship Education should also focus on three aspects, namely providing knowledge to students to become citizens of literate politics, develop the skills of learners in communicating through discussion, to develop the skills of learners to participate actively and responsibly in community activities (Watson, 2004). Thus, in the revitalization process should pay attention to three aspects such as the development direction of the material scope and competence.

The process of revitalizing the 2013's curriculum on pancasila and Pancasila and Citizenship Education subjects is a refinement of the curriculum of 2006's (SBC). It is not only in charge of content, but also in its nomenclature. Subjects of Pancasila and Citizenship Education (citizenships) which was originally known in Curriculum 2006 turned into Pancasila and Pancasila and Citizenship Education (PPKn). Completion is done on the basis of: (1) Pancasila as the state and outlook of the nation, played and interpreted as a core entity is a source of reference and criteria of success in achieving a level of competence and organization of the overall scope of subjects Pancasila and Pancasila and Citizenship Education; (2) the substance and spirit of the Constitution of the Republic of Indonesia Year 1945, the value and spirit of Unity in Diversity, and the commitment of the Republic of Indonesia placed as an integral part of Pancasila and Pancasila and Citizenship Education, which became a vehicle for psychological-pedagogical development of Indonesian nationals character of Pancasila.

Efforts to realize the goal of Pancasila and Pancasila and Citizenship Education has been set as competency standards that are qualifying criteria ability of graduates includes attitudes, knowledge, and skills. Competency standards based on competency in 21 st century that led to the establishment of a global citizen. According 
Shaogang Yang (2014: 6) requirements that need to be considered to set up a global citizen, among others: (1) the competence of cross-cultural communication in education should be improved (2) the state must have laws to strengthen the purpose of education in shaping citizens (3) universal values associated with global interests must be refined and analyzed scientifically, (4) education should encourage the country better than other countries.

According to Elizabeth O. Crawford (2013: 2) global citizen is someone who understands, respects and values diversity. Strategy Pancasila and Citizenship Education as an effort to prepare students to be global citizens in the 21 st century is built in with a global perspective that includes several aspects, among others, (1) a comprehensive knowledge of the political system of the world (2) a comprehensive knowledge about the world economy (3) thinking skills critical beyond the boundaries (4) cross-cultural communication skills (5) is active and (6) develop empathy (Shahla et al., 2013: 199). The sixth aspect of the global insight, it is necessary to develop the scope of the material in the formulation of the content standards that led to the global competence of learners.

\subsection{The Basis of Revitalization Process of 2013's Citizenship Curriculum subject}

The process of revitalizing the 2013's Pancasila and Citizenship Education curriculum subjects on the basis of reaching toward improving education of young people who have a sense of nationalism and patriotism towards their country. Juridical basis establishment of curriculum 2013's Pancasila and Pancasila and Citizenship Education subjects is (1) the Constitution of the Republic of Indonesia Year 1945, (2) of Law Number 20 Year 2003 on National Education System, (3) of Law Number 17 Year 2007 on long-term National Development plan, (4) of Government Regulation No. 19 Year 2005 on National Education Standards as amended by Government Regulation No. 32 Year 2013 regarding Amendment to Government Regulation No. 19 Year 2005 on National Education Standards.

The Results of the revitalization is in the form of curriculum in 2013 is a product of laws enacted by Ministerial Decision of National Education Republic of Indonesia as the embodiment of the educational policy established by the legislature which should have based on the constitution / basic. Constitution of the Republic of Indonesia Year 1945 is the supreme law as the basic norms that have binding force to the legal norms of legislation, or procedures outlined shaping legislation in General. All forms of government regulation of education and culture were issued as a legal product results of revitalizing 2013's Pancasila and Pancasila and Citizenship Education curriculum subjects should be based on the 1945 Constitution.

The second basis of curriculum development of 2013's Pancasila and Pancasila and Citizenship Education subjects, is Law No. 20 Year 2003 on National Education System. As Already mentioned in Article 2 that the national education serves to develop the ability and character development and civilization of the nation's dignity in the context of the intellectual life of the nation, is aimed at developing students' potentials in order to become a man of faith and fear of God Almighty, noble, healthy, knowledgeable, capable, creative, independent, and become citizens of a democratic and accountable. Article 36 paragraph (1) that the curriculum development conducted in accordance with national standards to achieve national education goals. Article 37 paragraph (1) section $b$ that the curriculum of primary and secondary education must include Pancasila and Pancasila and Citizenship Education. In order to achieve national education goals form the citizens of a democratic and responsible is one component in the learning Citizenship and Civics (Yvonne Haigh et al., 2014: 605). The formation process of citizenship that democracy does not occur naturally (Sharon Cook and Joel Westheimer, 2006: 348), but the need for the process, one through subjects Pancasila and Pancasila and Citizenship Education. Further Arthur and Davison (2000) argues that "citizenship" in this case is the Pancasila and Pancasila and Citizenship Education has been defined as a tool in the formation of passive and active citizens. So that citizens are not only aware of, understand, and act within the context of democratic participation, but also to contribute ideas to join in an active role in government policymaking idea.

Law No. 17 of 2005 concerning the National Development Plan has long been a third runway curriculum development in 2013 subjects Pancasila and Pancasila and Citizenship Education that is within its mission is to create a society that has high morals, ethics, culture, and based on the philosophy of Pancasila in order to strengthen the identity and character of the nation. The formation of national character can be done through character education. Ian Davies, et al (2005: 343) argues that character education is closely connected with Pancasila and Pancasila and Citizenship Education is both with regard to the problem of moral formation. So Pancasila and Pancasila and Citizenship Education is a strategic tool in realizing a long-term national development missions.

\subsection{Results of 2013 's Pancasila and Pancasila and Citizenship Education Subject Curriculum Revitalization}

Minister of Education and Culture policy contained in the Minister of Education and Culture No. 160 of 2014 on 
the Application of Curriculum 2006 and Curriculum 2013. Implementation of its improvements also on the basis of inputs from various walks input of public (civil society, professional associations, universities and education) to ideas, documents, and implementation of curriculum gained through monitoring and evaluation of the various media. Results of revitalization 2013's curriculum such as Pancasila and Citizenship subjects that contained in minister of education and culture policy is about graduation standards, content standards, standardized processes, and assessment standards. Of the four such standards are set by ministerial regulation of education and culture as the force of law in its implementation.

Graduates Competency Standards (SKL) is set in the Minister of Education and Culture No. 20 Year 2016 on Graduates Competency Standards and Secondary Education. Competency standards subjects Pancasila and Pancasila and Citizenship Education in Curriculum 2013 is the criteria regarding the qualifications of graduates capabilities that includes three dimensions that is the attitude, knowledge and skills. In accordance with what was put forward Branson, et al (1999) found three dimensions is the existing competence in Civics competence. To achieve the standard graduation of students, it is necessary to arrange the contents of the standard criteria to determine the scope and level of competence in accordance with the competence of graduates who have been formulated in the competency standards.

Content standards are the criteria concerning the scope of material and level of competence to achieve competence at the graduate level and type of education. In the 2013 curriculum subjects Pancasila and Pancasila and Citizenship Education stipulated in Minister of Education and Culture No. 21 of 2016 on the Content Standards for Primary and Secondary Education. The scope of materials developed in the standard content of each level is different. At the basic education level includes Pancasila values and morals, rights, obligations, and responsibilities of citizenship, social and cultural diversity and the interests of community, moral values and national unity, morality commendable in everyday life. Education Level of middle school include dynamics embodiment and moral values of Pancasila in daily life, the essence and moral values of Pancasila in the preamble of the Constitution of the Republic of Indonesia in 1945, the meaning of the applicable law in the embodiment of peace and justice, the spirit of unity in diversity of the communities, aspects of the strengthening of the Unitary Republic of Indonesia. At the secondary level above includes the ideal value, instrumental and practical principles of Pancasila, dynamics of the implementation of the provisions governing state finances and the judicial authorities, the dynamics of management and abuse by authorized state officials as well as handling (Corruption, Collusion and Nepotism), strategy set in a frame strengthen the unity with unity, the dynamics of the country and the Republic Indonesi concept and the concept of a federal state. From the distribution of the scope of the material at all levels of primary and secondary education in developed again in Core Competence and Basic Competence set out in the Regulation of the Minister of Education and Culture No. 24 of 2016 on Core Competence and Basic Competence Study On Curriculum 2013 On Basic Education and Secondary Education.

The substance of which has been prepared in the content standards to be implemented in the learning process in order to achieve graduation standards that have been set. Implementation of the learning process is organized in the Minister of Education and Culture No. 22 of 2016 on Standards for Primary and Secondary Education Process. This is a process standard criteria for the implementation of learning in the educational unit basic and secondary basic education units to achieve competence of graduates. In the instructional design process standards are designed in the form of syllabus and lesson plan that refers to the content standards. Learning plan includes the preparation of lesson plan and preparation of media and learning resources, assessment tools of learning, and learning scenarios. Of instructional design that had been developed by teachers, further implemented in the learning process through the introduction, core activities, and closing activity. Then to find out the level of achievement of the learning process should be assessed.

Curriculum 2013 subjects Pancasila and Pancasila and Citizenship Education assessment system has been set in its own regulations, namely Regulation of the Minister of Education and Culture No. 23 of 2016 concerning education Assessment Standards. Standard educational assessment in question is Criteria on Scope, Purpose, benefit, principle, mechanism, procedure and student's study grade result grading instrument used in elementary and junior high school. The grading system are based on authentic approach to see the readiness of the students, the process and study results intact. The perfect alignment of this three component will shows the capacity, style, and learning acquisition of the students which can make instructional effect on their knowledge aspect and additional effect on their attitude.

\section{Conclusion}

The Law politics of revitalization of the 2013's Pancasila and Pancasila and Citizenship Education subjects 
curriculum includes three components discussed in this article, namely (1) the policy direction revitalization subjects Pancasila and Pancasila and Citizenship Education refer to future needs and to meet the golden generation of Indonesia in 2045 in order to strengthen Indonesia's contribution to development of world civilization, 2) the legal basis underlying the implementation of the revitalization of the curriculum in 2013 subjects Pancasila and Pancasila and Citizenship Education is the process of curriculum development in 2013 is based on Pancasila as the state, law 1945 Constitution as the highest law in Indonesia, as well as law Education System of National and Act Law on the National Development Plan, (3) the results of revitalization and implementation of the curriculum in 2013 subjects Pancasila and Pancasila and Citizenship Education in the form of Regulation of Ministry of Education and culture of graduation competency standards, these standards, standardized processes, and standards assessment, of the four standard has been implemented in the process learning in schools at all educational units in Indonesia since this rule set that is dated June 28, 2016.

Curriculum development process continues to be done in order to follow the changing times and the development of science and technology so as not to miss the Indonesian nation with other nations. Results revitalization 2013 curriculum subjects Education Pancasila and citizenship that have to be implemented, monitoring and evaluation needs to be done to determine the level of achievement and expected results. Monitoring and evaluation results will serve as a recommendation to develop and or improve curriculum that will come.

\section{References}

Arthur, J., \& Davison, J. (2000). Social literacy and Citizenship Education in the school curriculum. The curriculum journal, 11(1). https://doi.org/10.1080/095851700361366.

Branson. (1998). The role of Citizenship Education. CALABASSAS: CCE.

Chikwe, M. (2012). Pancasila and Citizenship Education and global citizenship: a deweyan perspective. Journal of Peace Education and Social Justice, 6(3).

Cogan, J. J. (1999). Developing the civic Society: the role of Citizenship Education. Bandung: CICED.

Cook, S., \& Westheimer, J. (2006). Introduction: Democracy and Education. Canadian Journal of Education, 29(2), 347-358.

Crawford, E. O. (2013). Exploring our roles as global citizens. US: UNICEF's Education Department.

Departemen Pendidikan Nasional. (2006). Kurikulum Berbasis Kompetensi Mata Pelajaran Kewarganegaraan. Jakarta: Depdiknas.

Ghasempoor, A., dkk. (2012). Citizenship Education and Its Implication for Education. Journal of Education and Learning, 1(1).

Ian Davies, dkk. (2005). Citizenship Education and Character Education: Similarities and Contrasts. British Journal of Education Studies, 53(3). https://doi.org/10.1111/j.1467-8527.2005.00299.x.

Kerr, D. (2000). Citizenship Education: An international comparison across 16 countries. A paper presented at the American Educational Research Association Conference, in New Orleans USA.

Padmo Wahjono. (1986). Indonesia Negara Berdasarkan Atas Hukum. Jakarta: Ghalia Indonesia.

Padmo Wahjono. (1991). Menyelisik Proses Terbentuknya Peraturan Perundang-undangan. Presented on forum keadilan journal, No. 29, on April 1991.

Shahla, Z, dkk. (2013). Global Pancasila and Citizenship Education and its implications for curriculum goals at the age of globalization. Journal Internasional Education Studies, $6(1)$. https://doi.org/10.5539/ies.v6n1p195.

Silay, N. (2014). Another Type of Character Education: Citizenship Education. International Journal of Education, 6(2). https://doi.org/10.5296/ije.v6i2.4949

Sukmadinata, N. S. (2012). Pengembangan Kurikulum Teori dan Praktek. Bandung: PT Remaja Rosdakarya.

Watson, J. (2004). Education for citizenship-the emerging relationship between religious education and Citizenship Education. British Journal of Religious Education, 26(3). https://doi.org/10.1080/0141620042000232319.

Watz, M. (2011). An History Analisis of Character Education. Journal of Inquiry \& Action in Education, 4(2), 34-53.

Yang, S. (2014). The cultivation of global citizen with high quality: a time mission of chinese higher education. 
Filozofia Publiczna i Edukacja Demokratyczna, 2(2). https://doi.org/10.14746/fped.2014.3.2.13

Yvonne Haigh, dkk. (2014). Citizenship, civic education and politics: the education policy context for young Australian citizens. Journal of Education Policy, 29(5). https://doi.org/10.1080/02680939.2013.865080

Zembylas, M. (2009). Affect of citizenship, politics: its implication for education. Journal Pedagogy, Culture \& Society, 17(3). https://doi.org/10.1080/14681360903194376

\section{Copyrights}

Copyright for this article is retained by the author(s), with first publication rights granted to the journal.

This is an open-access article distributed under the terms and conditions of the Creative Commons Attribution license (http://creativecommons.org/licenses/by/4.0/). 